\title{
ANALISIS PERILAKU PENUMPANG PESAWAT TERHADAP PEMILIHAN RUTE PENERBANGAN DARI TAIPEI MENUJU JAKARTA (STUDI KASUS MAHASISWA INDONESIA STUDI DI TAIWAN)
}

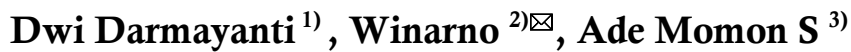

Jurusan Teknik Industri, Universitas Singaperbangsa Karawang

\section{Info Artikel}

Diserahkan Juli 2020

Diterima Oktober 2020

Diterbitkan Maret 2021

Kata Kunci:

Rute Penerbangan, Perilaku

Penumpang, Regresi

Logistik Multinomial
Abstrak

Penerbangan internasional dari Taipei menuju Jakarta dapat dilakukan melalui rute penerbangan langsung maupun tidak langsung. Pemilihan rute penerbangan tersebut dapat dipengaruhi oleh perilaku calon penumpang pesawat yang akan melakukan perjalanan. Penelitian ini dilakukan terhadap mahasiswa Indonesia yang sedang melanjutkan pendidikan di Taiwan. Metode regresi logistik multinomial digunakan untuk menganalisis faktor-faktor yang mempengaruhi mahasiswa tersebut dalam memilih rute penerbangan dari Taipei menuju Jakarta. Berdasarkan hasil analisis data terhadap 467 responden terpilih, menunjukkan bahwa reputasi bandara untuk transit, reputasi maskapai, harga tiket penerbangan, durasi penerbangan, kenyamanan dalam koneksi, hari penerbangan, dan jumlah bagasi adalah faktor-faktor yang mempengaruhi dalam pemilihan rute penerbangan tersebut. Faktor yang dominan berpengaruh terhadap pemilihan rute penerbangan internasional dari Taipei menuju Jakarta adalah faktor reputasi bandara transit dengan nilai odd ratio 5,668 dan 3,224 masing-masing pada rute Taipei-Singapura-Jakarta dan rute Taipei-HongkongJakarta. Sedangkan pada rute Taipei-Kuala Lumpur-Jakarta adalah faktor harga tiket dengan nilai odds ratio 4,669 dibandingkan dengan faktor yang lain.

(C) 2021 Indonesia

\begin{tabular}{cc}
\hline Alamat Korespondensi: & ISSN 2548-9909 \\
Jurusan Teknik Industri & \\
Universitas Singaperbangsa Karawang & \\
E-mail: winarno@staff.unsika.ac.id &
\end{tabular}

\section{Pendahuluan}

Transportasi berkaitan dengan pengangkutan benda dengan menggunakan berbagai jenis kendaraan sesuai dengan kemajuan teknologi (Akbar, 2019). Transportasi udara memiliki sarana dan prasarana yang menunjang dalam pemgelolaan jasa transporasi udara yaitu pesawat udara dan bandar udara (Setiani, 2015).

Transportasi udara sebagai sarana transportasi yang banyak dipilih karena efisiensi waktu dan kenyamanannya dibandingkan dengan alat transportasi darat dan transportasi laut. Akibatnya, banyak perusahaan maskapai penerbangan yang bermunculan. Maskapai penerbangan terus berlomba-lomba untuk menarik minat calon penumpang agar memilih perusahaannya dalam melakukan penerbangan baik domestik maupun internasional. Banyaknya perusahaam maskapai penerbangan ditandai dengan banyaknya pula rute perjalanan yang disediakan setiap maskapai (Akbar, 2019). Namun penerbangan pada saat ini mengalami penurunan menumpang. Menurut data angkutan udara yang dihimpun oleh Direktorat Jenderal Perhubungan Udara Kemenhub, terhitung pada Desember Tahun 2018 terdapat sebanyak 8,1 juta penumpang. Sementara pada Desember Tahun 2017 sebanyak 9 juta penumpang (Liputan6.com, 2019). 


Pihak perusahaan maskapai harus
mampu memahami perilaku $\begin{gathered}\text { calon } \\ \text { penumpangnya agar pelayanan yang diberikan }\end{gathered}$
dapat memenuhi harapan konsumen sehingga
dapat meningkatkan minat penumpang dalam
melakukan penerbangan domestik maupun
internasional. Menurut Husein Umar (2003),
perilaku penumpang merupakan tindakan-
tindakan atau hubungan sosial yang dilakukan
oleh perorangan maupun kelompok yang
dipengaruhi oleh aspek eksternal dan internal
yang mengarahkan mereka untuk memilih
mengkonsumsi produk.

Untuk mencapai tujuan ini, terdapat beberapa faktor yang mempengaruhinya. Menurut Jung \& Yoo (2016), akses kenyamanan emosional adalah faktor penting ketika memilih rute perjalanan. Rute penerbangan juga menjadi salah satu pilihan penumpang untuk mempertimbangkan biaya yang dikeluarkan mereka dalam sebuah perjalanan. Penelitian ini mengacu pada beberapa variabel yang digunakan oleh penelitian sebelumnya. Pada penelitian ini menggunakan faktor dari penelitian Rouncivell, Timmis, \& Ison (2018) dalam memilih maskapai yaitu reputasi maskapai, harga tiket, waktu penerbangan, dan kenyamanan koneksi. Faktor jadwal/hari penerbangan pada penelitian Leng \& Tan (2010). Sedangkan untuk faktor reputasi bandara transit, durasi terbang, durasi transit, metode pembayaran tiket, waktu reservasi, dan jumlah bagasi merupakan faktor tambahan yang digunakan dalam penelitian ini untuk mengetahui perilaku penumpang dalam memilih rute penerbangan. Dengan demikian, artikel ini menguatkan penelitian sebelumnya terhadap faktor-faktor karakteristik dalam pemilihan rute penerbangan dan sebagai sesuatu yang baru dilihat dari sisi obyek penelitian, yaitu mahasiswa sebagai responden.

Penerbangan domestik dan penerbangan internasional harus mampu memberikan pelayanan yang terbaik. Penerbangan internasional contohnya pada penerbangan di negara Taiwan yang menjadi tujuan besar para mahasiswa asal Indonesia untuk melanjutkan studi di Taiwan. Menurut Director Education
Division Taipei Economic and Trade Office (TETO), Taiwan termasuk dalam empat besar rekomendasi negara yang memberikan beasiswa dari pemerintahnya. Mahasiswa asal Indonesia berada di urutan ketiga sebagai mahasiswa asing terbanyak yang belajar di Taiwan, setelah Malaysia dan Jepang. Jumlah mahasiswa Indonesia yang kuliah di Taiwan mengalami peningkatan setiap tahunnya, yaitu sebanyak 5.000 dan 7.000 mahasiswa masing-masing pada tahun 2017 dan 2018 (Kompas.com, 2019). Dengan adanya potensi jumlah konsumen yang cukup besar tersebut, sangat penting bagi entitas sistem penerbangan seperti maskapai penerbangan maupun pengelola bandara yang termasuk ke dalam rute penerbangan TaiwanJakarta untuk memahami perilaku calon penumpang pesawat terbang. Dalam penelitian ini membahas analisis perilaku mahasiswa Indonesia yang studi di Taiwan sebagai calon penumpang pesawat terbang dari Taipei menuju Jakarta. Hasil penelitian ini diharapkan dapat menjadi bahan pertimbangan bagi entitas sistem penerbangan tersebut dalam membuat keputusan untuk meningkatkan kepuasan konsumen dan solusi bagi masyarakat yang akan melakukan penerbangan untuk memerhatikan faktor-faktor yang berpengaruh dalam memilih rute penerbangan dari Taipei ke Jakarta.

\section{Metode}

\subsection{Populasi dan Sampel}

Populasi merupakan wilayah generalisasi yang mempunyai karakteristik untuk ditarik kesimpulannya dan sampel merupakan bagian dari populasi yang memiliki jumlah dan karakteristik tertentu (Sugiyono, 2013). Dalam penelitian ini, mahasiswa asal Indonesia yang studi di Taiwan merupakan populasi yang akan dikaji. Sampel sebanyak 467 responden diambil dari populasi tersebut.

Penelitian ini merupakan penelitian deskriptif kuantitatif. Kuesioner dirancang untuk mengetahui informasi demografi dan faktorfaktor yang dipertimbangkan responden dalam pemilihan rute penerbangan dari Taipei menuju Jakarta. Adapun informasi demografi antara 
lain jenis kelamin, usia, pendapatan bulanan, pengeluaran bulanan, keikutsertaan program penerbangan, dan frekuensi penerbangan 2 (dua) tahun terakhir. Sedangkan faktor-faktor yang dipertimbangkan adalah reputasi bandara transit, reputasi maskapai, harga tiket, waktu keberangkatan, durasi terbang, durasi transit, kenyamanan koneksi, metode pembayaran tiket, waktu reservasi, hari penerbangan, dan jumlah bagasi. Faktor lain ditambahkan untuk mengakomodasi faktor selain dari responden yang telah disebutkan. Faktor Penyebaran kuesioner dilakukan baik secara online maupun offline pada Nopember 2018 - Februari 2019.

\subsection{Metode regresi Logistik Multinomial}

Regresi logistik adalah bagian dari analisis regresi yang menggunakan variabel dikotomi. Dikotomi yaitu variabel yang terdiri dari dua nilai (Herlina, 2019). Menurut Agresti (2002), regresi logistik merupakan metode yang dapat digunakan untuk mencari hubungan variabel bebas yang bersifat dichotomous (berskala nominal atau ordinal dengan dua kategori) atau polychotomous (mempunyai skala nominal atau ordinal dengan lebih dari dua kategori) dengan satu atau lebih variabel bebas dan variabel terikat bersifat kontinyu atau kategorik.

Metode analisis terhadap data yang telah terkumpul dari penyebaran kuesioner adalah regresi logistik multinomial, yaitu regresi logistik biner yang diperluas dengan variabel dependen mempunyai kategori lebih dari dua (Ghozali, 2013). Model matematis dari regresi logistik multinomial:

$$
\begin{array}{r}
\operatorname{Logit} P(Y=0,1,2,3)=\beta_{0}+\beta_{1} X_{1}+\beta_{2} X_{2}+ \\
{ }_{3} X_{3}+\cdots+\beta_{12} X_{12}
\end{array}
$$

Logit adalah logaritma natural. $P$ adalah probabilitas penumpang memilih rute penerbangan tertentu, dimana $Y=1$ jika memilih rute Taipei-Jakarta, $Y=2$ jika memilih rute Taipei-Singapura-Jakarta, $Y=3$ jika memilih rute Taipei-Kuala Lumpur-Jakarta, dan $Y=4$ jika memilih rute Taipei-Hongkong-Jakarta. Sedangkan $\beta_{0}$ adalah nilai konstanta dari persamaan regresi, $X_{1}$ adalah reputasi bandara transit, $X_{2}$ merupakan reputasi maskapai, $X_{3}$ merupakan harga tiket, $X_{4}$ adalah waktu keberangkatan, $X_{5}$ menyatakan durasi terbang, $X_{6}$ menyatakan durasi transit, $X_{7}$ menunjukkan kenyamanan koneksi, $X_{8}$ adalah metode pembayaran tiket, $X_{9}$ merupakan waktu reservasi, $X_{10}$ adalah hari penerbangan, $X_{11}$ menyatakan jumlah bagasi, dan $X_{12}$ merupakan faktor lainnya.

Setelah data terkumpul, kemudian diolah menggunakan program IBM SPSS Statistic 23, dan selanjutnya dianalisis untuk mendapatkan suatu kesimpulan dari permasalahan yang ada. Gambar 1 memaparkan langkah analisis penelitian. Berdasarkan Gambar 1, maka langkah analisis penelitian dimulai dengan (Novela Sari, 2017):

1. Mendeskripsikan data. Data yang diperoleh dianalisis dengan statitik deskriptif.

2. Selanjutnya melakukan uji independensi dengan memeriksa tiap variabel independen dan variabel dependen menggunakan chi square.

3. Estimasi parameter pada data faktor yang mempengaruhi pemilihan rute penerbangan internasional dari Taipei menuju Jakarta.

4. Melakukan uji signifikansi parameter secara serentak untuk mengetahui model yang tepat berdasarkan faktor-faktor yang mempengaruhi pemilihan rute penerbangan internasional dari Taipei menuju Jakarta.

5. Melakukan uji signifikansi parameter secara parsial untuk mengetahui faktor-faktor yang mempengaruhi pemilihan rute penerbangan internasional dari Taipei menuju Jakarta.

6. Estimasi parameter pada data faktor yang mempengaruhi pemilihan rute penerbangan internasional dari Taipei menuju Jakarta dengan variabel yang signifikan.

7. Melakukan uji signifikansi parameter secara serentak untuk mengetahui model yang tepat berdasarkan faktor-faktor yang mempengaruhi pemilihan rute penerbangan internasional dari Taipei menuju Jakarta dengan variabel yang signifikan.

8. Melakukan uji signifikansi parameter secara parsial untuk mengetahui faktor-faktor yang mempengaruhi pemilihan rute penerbangan 
internasional dari Taipei menuju Jakarta dengan variabel yang signifikan.

9. Menganalisis odds ratio pada data pemilihan rute penerbangan internasional dari Taipei menuju Jakarta.

10. Melakukan uji kesesuain model untuk mengetahui apakah model pada data pemilihan rute penerbangan internasional dari Taipei menuju Jakarta telah sesuai atau tidak. Model sesuai apabila antara hasil observasi dan prediksi dinyatakan sama.

11. Melakukan identifikasi ketepatan klasifikasi untuk mengetahui tingkat kelayakan suatu model pada pemilihan rute penerbangan internasional dari Taipei menuju Jakarta dengan melihat seberapa besar presentase observasi yang diklasifikasikan secara tepat.

12. Menarik kesimpulan dan saran.

\section{Hasil dan Pembahasan}

\subsection{Data Demografi Responden}

Analisis deskriptif merupakan pengolahan data mengenai identitas responden yang berisi data demografi dengan tujuan untuk mendapatkan profiling responden. Data disajikan pada Tabel 1.

\subsection{Analisis Deskriptif Variabel Penelitian}

Analisis deskriptif bertujuan untuk mengetahui gambaran atau sebaran data sehingga menghasilkan informasi yang bermanfaat. Dalam penelitian ini, dilakukan analisis deskriptif terhadap variabel respon pemilihan rute penerbangan internasional dari Taipei menuju Jakarta dengan variabel prediktor berupa semua faktor yang telah diuraikan dalam subbab 2.1.

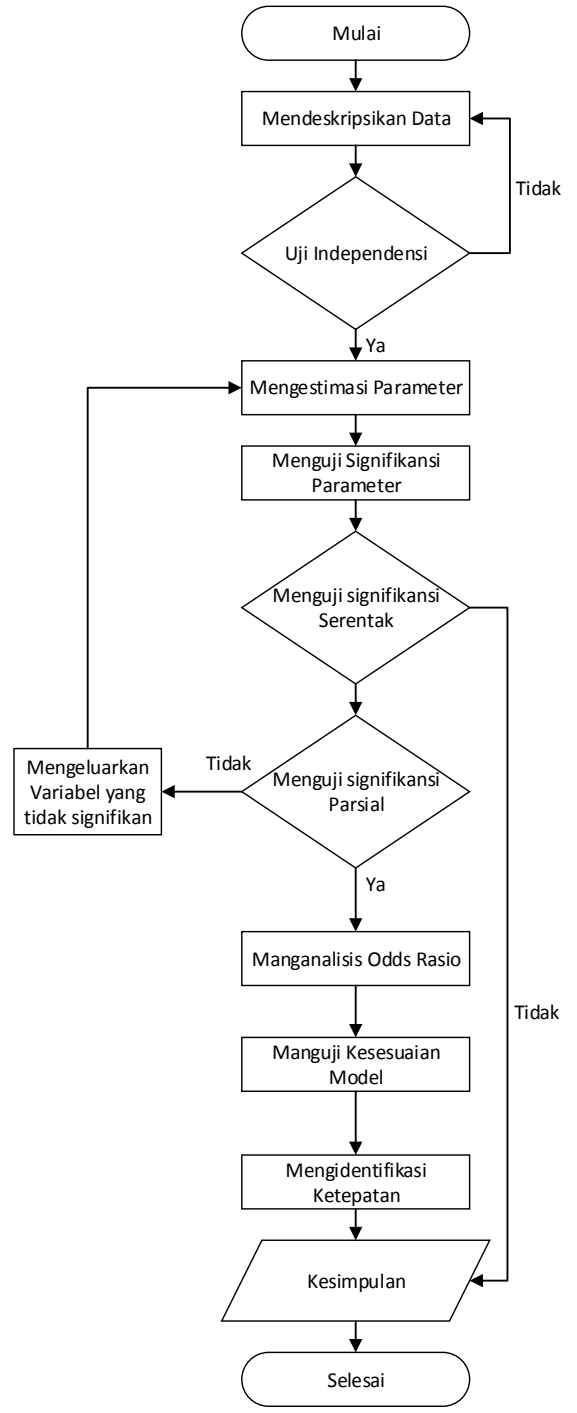

Gambar .1. Flowchart Analisis Penelitian

Tabel 1. Data Demografi Responden

\begin{tabular}{|l|l|l|}
\hline Demografi & N & $\%$ \\
\hline Jenis Kelamin & \multicolumn{2}{|l|}{} \\
\hline Pria & 239 & 51,1 \\
\hline Perempuan & 228 & 48,9 \\
\hline Total & 467 & 100 \\
\hline Usia \\
\hline $17-19$ tahun & 54 & 11,60 \\
\hline $20-24$ tahun & 186 & 39,80 \\
\hline $25-29$ tahun & 135 & 28,9 \\
\hline $30-34$ tahun & 47 & 10,10 \\
\hline $35-39$ tahun & 22 & 4,70 \\
\hline $410-44$ tahun & 18 & 3,90 \\
\hline 46 ke atas & 5 & 1,10 \\
\hline Total & 467 & 100 \\
\hline
\end{tabular}




\begin{tabular}{|c|c|c|}
\hline \multicolumn{3}{|c|}{ Jenjang Pendidikan } \\
\hline Sarjana & 96 & 20,60 \\
\hline Magister & 236 & 50,50 \\
\hline Doktor & 135 & 28,90 \\
\hline Total & 467 & 100 \\
\hline \multicolumn{3}{|l|}{ Biaya Studi } \\
\hline Orang Tua & 143 & 30,60 \\
\hline Beasiswa Kampus & 307 & 65,70 \\
\hline $\begin{array}{l}\text { Beasiswa } \\
\text { Pemerintah } \\
\text { Taiwan }\end{array}$ & 47 & 10,10 \\
\hline $\begin{array}{l}\text { Kerja Paruh } \\
\text { Waktu }\end{array}$ & 117 & 25,10 \\
\hline $\begin{array}{l}\text { Beasiswa } \\
\text { Pemerintah Lokal }\end{array}$ & 21 & 4,50 \\
\hline Lainnya & 26 & 5,60 \\
\hline Total & 467 & 100 \\
\hline \multicolumn{3}{|l|}{ Pendapatan (\$NT) } \\
\hline Dibawah 20,001 & 352 & 75,40 \\
\hline $20,001-30,000$ & 77 & 16,50 \\
\hline $30,001-40,000$ & 29 & 6,20 \\
\hline $40,001-50,000$ & 4 & 0,90 \\
\hline $50,001-60,000$ & 3 & 0,60 \\
\hline 60,001 keatas & 2 & 0,40 \\
\hline Total & 467 & 100 \\
\hline \multicolumn{3}{|l|}{ Pengeluaran (\$NT) } \\
\hline Dibawah 15,001 & 334 & 71,50 \\
\hline $15,001-18,000$ & 68 & 14,60 \\
\hline $18,001-21,000$ & 26 & 5,60 \\
\hline $21,001-25,000$ & 18 & 3,90 \\
\hline 25,001 keatas & 21 & 4,50 \\
\hline Total & 467 & 100 \\
\hline \multicolumn{3}{|l|}{ Frequent Flayer } \\
\hline $\mathrm{Ya}$ & 129 & 27,60 \\
\hline Tidak & 338 & 72,40 \\
\hline Total & 467 & 100 \\
\hline \multicolumn{3}{|c|}{ Riwayat Penerbangan } \\
\hline Belum Pernah & 80 & 17,10 \\
\hline 1 Kali & 156 & 33,40 \\
\hline 2 Kali & 118 & 25,30 \\
\hline 3 Kali & 52 & 11,10 \\
\hline Lebih dari 3 Kali & 61 & 13,10 \\
\hline Total & 467 & 100 \\
\hline
\end{tabular}

3.1 Analisis Regresi Logistik Multinomial

\section{Uji Independensi}

Uji independensi digunakan untuk mengetahui ada atau tidaknya hubungan antara pemilihan rute penerbangan dengan faktorfaktor yang diduga mempengaruhi pemilihan rute penerbangan internasinal dari Taipei menuju Jakarta. Berikut uji independensi dengan hipotesis:

$H_{0}$ : Tidak ada hubungan antara pemilihan rute penerbangan internasional terhadap faktorfaktor yang diduga memengaruhinya.

$H_{1}$ : Ada hubungan antara pemilihan rute penerbangan internasional terhadap faktorfaktor yang diduga memengaruhinya.

Wilayah kritis/area penolakan $H_{0}$ adalah jika $P$ value $<\alpha(0,05)$. Hasil pengolahannya disajikan pada Tabel 2 .

Tabel 2. Hasil Uji Independensi

\begin{tabular}{|l|l|}
\hline \multicolumn{1}{|c|}{ Variabel Independen } & $P$-value \\
\hline Reputasi Bandara Transit & 0,000 \\
\hline Reputasi Maskapai & 0,019 \\
\hline Harga Tiket & 0,001 \\
\hline Waktu Keberangkatan & 0,090 \\
\hline Durasi Terbang & 0,000 \\
\hline Durasi Transit & 0,311 \\
\hline Kenyamanan Koneksi & 0,011 \\
\hline Metode Pembayaran Tiket & 0,076 \\
\hline Waktu Reservasi & 0,385 \\
\hline Hari Penerbangan & 0,010 \\
\hline Jumlah Bagasi & 0,007 \\
\hline Faktor Lainnya & 0,638 \\
\hline
\end{tabular}

Berdasarkan Tabel 2, variabel reputasi bandara transit, reputasi maskapai, harga tiket, durasi terbang, kenyamanan koneksi, hari penerbangan, dan jumlah bagasi memiliki hubungan terhadap pemilihan rute penerbangan internasional dari Taipei menuju Jakarta. Hal ini terlihat pada nilai $P$-value kurang dari $<\alpha$ $(0,05)$.

\section{Uji Regresi Logistik Multinomial}

Model regresi dengan variabel dependen berskala nominal empat kategori digunakan 
kategori variabel hasil $Y$ dikodekan menjadi 1, 2, 3 dan 4 . Variabel $Y$ terparameterisasi menjadi tiga fungsi logit. Sebelumnya perlu ditentukan kategori hasil mana yang digunakan untuk membandingkan. Pada umumnya digunakan $Y=1$ sebagai pembanding. Hasil estimasi parameter dibentuk dalam model logit

$$
\begin{aligned}
\mathrm{g}_{2}(\mathrm{x})= & -0,822+1,737 X_{1}-0,479 X_{2}+ \\
& 0,627 X_{3}-1,374 X_{4}+0,418 X_{5}- \\
& 0,579 X_{6}-0,462 X_{7} \\
\mathrm{~g}_{3}(\mathrm{x})= & -1,981+0,487 X_{1}-0,288 X_{2}+ \\
& 1,547 X_{3}-1,434 X_{4}+0,651 X_{5}+ \\
& 0,458 X_{6}-0,590 X_{7} \\
\mathrm{~g}_{4}(\mathrm{x})= & -3,559+1,146 X_{1}+0,941 X_{2}+ \\
& 0,485 X_{3}-1,069 X_{4}+0,743 X_{5}+ \\
& 0,875 X_{6}-1,460 X_{7}
\end{aligned}
$$

\section{Uji Sigifikansi Parameter}

Pengujian signifikansi parameter dilakukan untuk mengetahui faktor-faktor yang signifikan terhadap pemilihan rute penerbangan dengan faktor-faktor yang diduga memengaruhi pemilihan rute penerbangan internasional dari Taipei menuju Jakarta.

\section{Uji Serentak}

Berikut pengujian signifikansi parameter secara serentak dengan hipotesis:

$H_{0}: \quad \beta_{1}=\beta_{2}=\cdots=0 \quad$ (Tidak ada satupun variabel yang secara statistik signifikan memengaruhi pemilihan rute)

$H_{1}$ : Minimal ada satu $\beta_{i} \neq 0$, (Minimal terdapat satu variabel yang secara statistik signifikan memengaruhi pemilihan rute)

Wilayah kritis/area penolakan $H_{0}$ : jika $G^{2}>$ $\chi_{a, \mathrm{df}}^{2}$ serta $P$-value $<\propto(0,05)$. Hasil perhitungan disajikan pada Tabel 3.

Tabel 3. Estimasi Parameter Secara Serentak

\begin{tabular}{|l|l|l|l|l|}
\hline$G^{2}$ & $\propto$ & df & $\chi_{(0,05,21)}^{2}$ & $P$ - \\
\hline
\end{tabular}

\begin{tabular}{|l|l|l|l|l|}
\hline & & & & value \\
\hline 406,093 & 0,05 & 21 & 32,6706 & 0,000 \\
\hline
\end{tabular}

Keputusan yang diperoleh berdasarkan Tabel 2 adalah tolak $H_{0}$. Hal ini dikarenakan nilai $G^{2}(406,093)>\chi_{(0,05,21)}^{2}(32,6706$ serta nilai $P$-value $(0,000)<\propto(0,05)$, artinya terdapat minimal satu variabel yang signifikan terhadap pemilihan rute penerbangan internasional dari Taipei menuju Jakarta.

\section{Uji Parsial}

Uji parsial digunakan untuk pengujian individu yang menunjukkan apakah suatu variabel bebas signifikan atau layak untuk masuk model atau tidak.

Hipotesis:

$H_{0}: \beta_{i}=0$ (Variabel independen ke- $i$ secara statistik tidak signifikan terhadap pemilihan rute)

$H_{1}: \beta_{1} \neq 0$ (Variabel independen ke- $i$ secara statistik signifikan terhadap pemilihan rute)

Wilayah kritis/area penolakan $H_{0}$ : jika nilai $W>$

\begin{tabular}{|c|c|c|c|c|}
\hline Rute & Parameter & $B$ & Wald & $\begin{array}{l}P \text { - } \\
\text { value }\end{array}$ \\
\hline \multirow{6}{*}{ 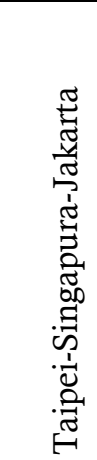 } & Intercept &,- 822 & 8,520 & ,004 \\
\hline & $\begin{array}{l}\text { Reputasi } \\
\text { Bandara } \\
\text { Transit }\end{array}$ & 1,737 & $\begin{array}{l}44,08 \\
6\end{array}$ & ,000 \\
\hline & $\begin{array}{l}\text { Reputasi } \\
\text { Maskapai }\end{array}$ &,- 479 & 3,332 & ,068 \\
\hline & $\begin{array}{l}\text { Harga } \\
\text { Tiket }\end{array}$ & ,627 & 5,216 & ,022 \\
\hline & $\begin{array}{l}\text { Durasi } \\
\text { Terbang }\end{array}$ & $\begin{array}{l}- \\
1,374\end{array}$ & $\begin{array}{l}27,90 \\
8\end{array}$ & , 000 \\
\hline & Kenyama & ,418 & 2,540 & 111 \\
\hline
\end{tabular}
$Z_{\alpha / 2}$. Nilai $Z_{\alpha / 2}$ sebesar 1,96 didapat dari tabel $Z_{0,025}$.

Perhitungan dilakukan dengan menggunakan program IBM SPSS Statistic 23 dengan rute penerbangan langsung TaipeiJakarta sebagai kategori referensi. Estimasi parameter secara parsial disajikan pada Tabel 4 .

Tabel 4. Estimasi Parameter Secara Parsial 


\begin{tabular}{|c|c|c|c|c|}
\hline & $\begin{array}{l}\text { nan } \\
\text { Koneksi }\end{array}$ & & & \\
\hline & $\begin{array}{l}\text { Hari } \\
\text { Penerbang } \\
\text { an }\end{array}$ &,- 579 & 2,255 & 133 \\
\hline & $\begin{array}{l}\text { Jumlah } \\
\text { Bagasi }\end{array}$ &,- 462 & 2,441 & ,118 \\
\hline \multirow{8}{*}{$\begin{array}{l}\text { Taipei- } \\
\text { Kuala } \\
\text { Lumpu } \\
\text { r- } \\
\text { Jakarta }\end{array}$} & Intercept & $\begin{array}{l}- \\
1,981\end{array}$ & $\begin{array}{l}22,73 \\
1\end{array}$ & ,000 \\
\hline & $\begin{array}{l}\text { Reputasi } \\
\text { Bandara } \\
\text { Transit }\end{array}$ & ,487 & 2,120 & 145 \\
\hline & $\begin{array}{l}\text { Reputasi } \\
\text { Maskapai }\end{array}$ &,- 288 & ,778 & ,378 \\
\hline & $\begin{array}{l}\text { Harga } \\
\text { Tiket }\end{array}$ & 1,547 & $\begin{array}{l}14,24 \\
8\end{array}$ & ,000 \\
\hline & $\begin{array}{l}\text { Durasi } \\
\text { Terbang }\end{array}$ & $-\overline{1,434}$ & $\begin{array}{l}18,49 \\
3 \\
\end{array}$ & ,000 \\
\hline & $\begin{array}{l}\text { Kenyama } \\
\text { nan } \\
\text { Koneksi }\end{array}$ & ,651 & 3,928 & ,048 \\
\hline & $\begin{array}{l}\text { Hari } \\
\text { Penerbang } \\
\text { an }\end{array}$ & ,458 & 1,240 & 265 \\
\hline & $\begin{array}{l}\text { Jumlah } \\
\text { Bagasi }\end{array}$ &,- 590 & 2,696 & 101 \\
\hline \multirow{8}{*}{ 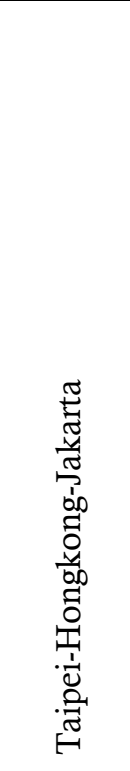 } & Intercept & $\begin{array}{l}-559 \\
3,59\end{array}$ & $\begin{array}{l}30,50 \\
2\end{array}$ & ,000 \\
\hline & $\begin{array}{l}\text { Reputasi } \\
\text { Bandara } \\
\text { Transit }\end{array}$ & 1,146 & 5,643 & ,018 \\
\hline & $\begin{array}{l}\text { Reputasi } \\
\text { Maskapai }\end{array}$ & 941 & 2,853 & ,091 \\
\hline & $\begin{array}{l}\text { Harga } \\
\text { Tiket }\end{array}$ & ,804 & 2,286 & 131 \\
\hline & $\begin{array}{l}\text { Durasi } \\
\text { Terbang }\end{array}$ & $\begin{array}{l}- \\
1,069\end{array}$ & 4,612 & ,032 \\
\hline & $\begin{array}{l}\text { Kenyama } \\
\text { nan } \\
\text { Koneksi }\end{array}$ & ,743 & 2,342 & ,126 \\
\hline & $\begin{array}{l}\text { Hari } \\
\text { Penerbang } \\
\text { an }\end{array}$ & 875 & 2,542 & ,111 \\
\hline & $\begin{array}{l}\text { Jumlah } \\
\text { Bagasi }\end{array}$ & $\begin{array}{l}- \\
1,260\end{array}$ & 4,566 & 033 \\
\hline
\end{tabular}

Berdasarkan Tabel 4, bahwa variabel reputasi bandara transit, reputasi maskapai, harga tiket, durasi terbang, kenyamanan koneksi, hari penerbangan, dan jumlah bagasi pada pemilihan rute Taipei-Singapura-Jakarta diperoleh nilai wald masing-masing sebesar 44,$086 ; 3,332 ; 5,216 ; 27,908 ; 2,540 ; 2,255$; dan 2,441 lebih besar dari nilai $Z_{\alpha / 2}$ sebesar 1,96 . Variabel reputasi bandara transit, harga tiket, durasi terbang, kenyamanan koneksi, dan jumlah bagasi pada pemilihan rute Taipei-Kuala Lumpur-Jakarta diperoleh nilai wald masingmasing sebesar 2,120; 14,248; 18,493; 3,928; dan 2,696 lebih besar dari nilai $Z_{\alpha / 2}$ sebesar 1,96. Variabel reputasi bandara transit, reputasi maskapai, harga tiket, durasi terbang, durasi, kenyamanan koneksi, hari penerbangan, dan jumlah bagasi pada pemilihan rute TaipeiHongkong-Jakarta diperoleh nilai wald masingmasing sebesar 5,$643 ; 2,853 ; 2,286 ; 4,612 ; 2,342$; 2,542; dan 4,566 lebih besar dari nilai $Z_{\alpha / 2}$ sebesar 1,96. Sehingga variabel-variabel tersebut berpengaruh signifikan terhadap pemilihan rute penerbangan internasional dari Taipei menuju Jakarta.

\section{Odds Ratio}

Odds Ratio yang digunakan untuk mengetahui kecenderungan faktor-faktor yang signifikan terhadap pemilihan rute penerbangan internasional dari Taipei menuju Jakarta. Nilai odds ratio yang diperoleh disajikan pada Tabel 5.

Tabel 5. Nilai Odds Ratio

\begin{tabular}{|c|c|c|}
\hline Rute & Parameter & $\operatorname{Exp}(\mathrm{B})$ \\
\hline \multirow{7}{*}{ 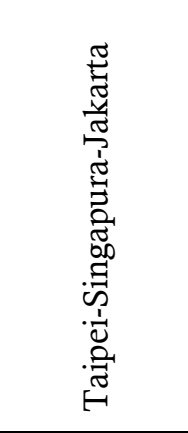 } & $\begin{array}{l}\text { Reputasi Bandara } \\
\text { Transit }\end{array}$ & 5,679 \\
\hline & Reputasi Maskapai & ,619 \\
\hline & Harga Tiket & 1,871 \\
\hline & Durasi Terbang & 253 \\
\hline & $\begin{array}{l}\text { Kenyamanan } \\
\text { Koneksi }\end{array}$ & 1,518 \\
\hline & Hari Penerbangan & ,561 \\
\hline & Jumlah Bagasi & ,630 \\
\hline \multirow{5}{*}{ 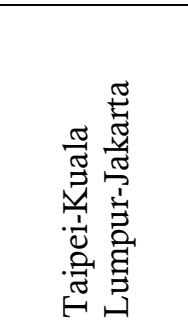 } & $\begin{array}{l}\text { Reputasi Bandara } \\
\text { Transit }\end{array}$ & 1,627 \\
\hline & Harga Tiket & 4,699 \\
\hline & Durasi Terbang & ,238 \\
\hline & $\begin{array}{l}\text { Kenyamanan } \\
\text { Koneksi }\end{array}$ & 1,917 \\
\hline & Jumlah Bagasi &, 554 \\
\hline \multirow{4}{*}{$\begin{array}{l}\text { Taipei- } \\
\text { Hongkong- } \\
\text { Jakarta }\end{array}$} & $\begin{array}{l}\text { Reputasi Bandara } \\
\text { Transit }\end{array}$ & 3,144 \\
\hline & Reputasi Maskapai & 2,562 \\
\hline & Harga Tiket & 2,234 \\
\hline & Durasi Terbang & ,343 \\
\hline
\end{tabular}




\begin{tabular}{|l|l|l|}
\hline & $\begin{array}{l}\text { Kenyamanan } \\
\text { Koneksi }\end{array}$ & 2,102 \\
\cline { 2 - 3 } & Hari Penerbangan & 2,398 \\
\cline { 2 - 3 } & Jumlah Bagasi &, 284 \\
\hline
\end{tabular}

Berdasarkan Tabel 5, dapat dijelaskan bahwa faktor reputasi bandara transit pada pemilihan rute Taipei-Singapura-Jakarta memiliki nilai kecenderungan lebih besar $(5,679)$ dari faktor yang lain. Ini menunjukkan bahwa faktor reputasi maskapai, harga tiket, durasi terbang, dan kenyamanan koneksi kurang signifikan dari reputasi bandara transit. Sedangkan faktor harga tiket pada pemilihan rute Taipei-Kuala Lumpur-Jakarta memiliki nilai kecenderungan lebih besar $(4,669)$ dari faktor yang lain. Ini menunjukkan faktor reputasi bandara transit, reputasi maskapai, durasi terbang, kenyamanan koneksi, dan jumlah bagasi kurang signifikan dari harga tiket. Namun faktor reputasi bandara transit pada pemilihan rute Taipei-Hongkong-Jakarta memiliki nilai kecenderungan lebih besar $(3,144)$ dari faktor lainnya. Hal ini menunjukkan bahwa faktor reputasi maskapai, harga tiket, durasi terbang, kenyamanan koneksi, hari penerbangan, dan jumlah bagasi kurang signifikan dari reputasi bandara transit.

\section{Uji Kesesuain Model}

Uji kesesuaian model dalam analisis regresi logistik dilakukan untuk mengetahui adanya perbedaan atau tidak antara hasil observasi dengan kemungkinan hasil prediksi model.

Hipotesis:

$H_{0}$ : Model sesuai (tidak ada perbedaan yang signifikan antara hasil pengamatan dengan kemungkinan hasil prediksi)

$H_{1}$ : Model tidak sesuai (terdapat perbedaan yang signifikan antara hasil pengamatan dengan kemungkinan hasil prediksi)

Wilayah kritis/area penolakan $H_{0}$ :

Jika $\chi^{2}>\chi_{(\mathrm{df}, \alpha)}^{2}$ dan $P$-value $>\alpha(0,05)$.

Hasil perhitungan yang telah dilakukan diperoleh nilai-nilai sebagai berikut: $G^{2}$ sebesar 266,349; $d f$ sebesar 264; $\chi_{(\mathrm{df}, \alpha)}^{2}$ sebesar 302,8983; dan p-value sebesar 0,448. Berdasarkan hasil perhitungan tersebut, keputusan yang diambil adalah gagal tolak $H_{0}$ karena nilai $\chi^{2}$ kurang dari $\chi_{(264,0,05)}^{2}$ atau $P$-value lebih dari nilai $\alpha(0,05)$. Maka model telah sesuai atau tidak terdapat perbedaan yang signifikan antara hasil pengamatan dengan kemungkinan hasil prediksi model.

\section{Ketetapan Klasifikasi Model}

Ketetapan klasifikasi model dilakukan untuk mengetahui apakah data prediksi telah diklasifikasikan diklasifikasikan dengan benar atau tidak sesuai dengan data observasinya. Berikut ketetapan klasifikasi model disajikan pada Tabel 7. Dalam Tabel 7, T, S, KL, H, dan $\mathrm{J}$ menunjukkan masing-masing Taipei, Singapura, Kuala Lumpur, Hongkong, dan Jakarta.

Tabel 7.Ketetapan Klasifikasi Model

\begin{tabular}{|c|c|c|c|c|c|}
\hline \multirow{2}{*}{ 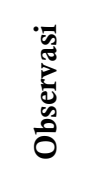 } & \multicolumn{5}{|c|}{ Prediksi } \\
\hline & T-J & T-S-J & $\begin{array}{l}\text { T- } \\
\text { KL-J }\end{array}$ & $\begin{array}{l}\text { T-H- } \\
\text { J }\end{array}$ & $\%$ \\
\hline T-J & 226 & 25 & 0 & 1 & 89,68 \\
\hline T-S-J & 62 & 70 & 1 & 0 & 52,63 \\
\hline $\begin{array}{l}\text { T-KL- } \\
\text { J }\end{array}$ & 41 & 18 & 0 & 0 & 0,00 \\
\hline T-H-J & 14 & 8 & 1 & 0 & 0,00 \\
\hline$\%$ & 73,45 & 25,91 & 0,43 & 0,21 & 63,38 \\
\hline
\end{tabular}

Nilai apparent error rate (APER) menyatakan suatu nilai yang digunakan untuk melihat peluang kesalahan dalam mengklasifikasikan objek.

$$
\begin{aligned}
A P E R & =\frac{226+70+0+0}{467} \times 100 \% \\
& =63,38 \%
\end{aligned}
$$

Artinya model mampu mengklasifikasikan secara tepat dari data sebesar $63,38 \%$.

\section{Kesimpulan}


Berdasarkan hasil penelitian dan pembahasan pada penelitian ini dapat ditarik kesimpulan bahwa faktor yang secara statistik signifikan mempengaruhi penumpang dalam pemilihan rute penerbangan Taipei-SingapuraJakarta dan Taipei-Hongkong-Jakarta adalah reputasi bandara untuk transit, reputasi maskapai, harga tiket penerbangan, durasi penerbangan, kenyamanan dalam koneksi, hari penerbangan, dan jumlah bagasi. Sedangkan faktor yang secara statistik signifikan mempengaruhi penumpang dalam pemilihan rute penerbangan Taipei-Kuala Lumpur-Jakarta adalah reputasi bandara untuk transit, harga tiket penerbangan, durasi penerbangan, kenyamanan dalam koneksi, dan jumlah bagasi.

Faktor yang dominan memengaruhi pemilihan rute Taipei-Singapura-Jakarta dan Taipei-Hongkong-Jakarta adalah faktor reputasi bandara transit dengan nilai odds ratio masingmasing 5,679 dan 3,144. Sedangkan pada rute Taipei-Kuala Lumpur-Jakarta adalah faktor harga tiket dengan nilai odds ratio 4,669 dibandingkan dengan faktor yang lain.

\section{Daftar Pustaka}

Agresti, A. (2002). Ctegorical Data Analysis Second Edition (Canada). A John Wiley \& Sons, Inc, Hoboken, New Jersey. Canada.

Akbar, M. F. (2019). Kualitas Pelayanan Pt Jasa Angkasa Semesta Di Bandar Udara Internasional Soekarno-Hatta Jakarta. Sekolah Tinggi Pariwisata Bandung.

Ghozali, I. (2013). Imam Ghozali (Viii). Semarang: Badan Penerbit Universitas Diponegoro.

Herlina, V. (2019). Panduan Praktis Mengolah Data Kuesioner Menggunakan Spss. Jakarta: Pt. Elix Media Komputindo.

Jung, S., \& Yoo, K. (2016). A Study On Passengers ' Airport Choice Behavior Using Hybrid Choice Model : A Case Study Of Seoul Metropolitan Area, South Korea. Journal of Air Transport Management, $\quad 57, \quad 70-79$. Https://Doi.Org/10.1016/J.Jairtraman.20 16.07.007

Kompas.Com. (2019). 5 Faktor Penyebab Milenial Indonesia Memilih Kuliah Di Taiwan. Retrieved June 2, 2020, From Https://Www.Kompas.Com/Regional/R ead/2019/03/12/21372881/5-Faktor-
Penyebab-Milenial-Indonesia/Memilih-

Kuliah-Di-Taiwan

Leng, W., \& Tan, A. K. G. (2010). A Note On The Determinants of Airline Choice : The Case Of Air Asia And Malaysia Airlines. Journal of Air Transport Management, 16(4), 209-212. Https://Doi.Org/10.1016/J.Jairtraman.20 09.06.001

Liputan6.Com. (2019). Industri Penerbangan Jadi Pendorong Pertumbuhan Ekonomi Indonesia. Retrieved June 2, 2020, From Https://Www.Liputan6.Com/Bisnis/Rea d/3892265/Industri-Penerbangan-JadiPendorong-Pertumbuhan-EkonomiIndonesia

Novela Sari, S. (2017). Faktor-Faktor Yang Mempengaruhi Tindakan Kriminal Di Kota Surabaya Tahun 2016 Dengan Metode Regresi Logistik Multinomial. Institut Teknologi Sepuluh Nopember.

Rouncivell, A., Timmis, A. J., \& Ison, S. G. (2018). Willingness To Pay For Preferred Seat Selection On Uk Domestic Flights. Journal of Air Transport Management, 70(April), 57-61. Https://Doi.Org/10.1016/J.Jairtraman.20 18.04.018

Setiani, B. (2015). Prinsip-Prinsip Pokok Pengelolaan Jasa. Jurnal Ilmiah Widya Volume 3 Nomor 2 September - Desember 2015, 3(2).

Sugiyono, P. D. (2013). Metode Penelitian Kuantitatif, Kualitatif, Dan $R \& D$. Bandung: Alfabeta.

Umar, H. (2003). Riset Pemasaran Dan Perilaku Konsumen. Jakarta: Gramedia Pustaka Utama. 